\title{
Aldersrelatert makuladegenerasjon: Informasjonsmøte på kveldstid gir tryggere pasienter
}

Kveldsmøtene på øyeavdelingen ved Stavanger universitetssjukehus har vært en suksess. Pasientene fikk mer kunnskap og kunne lettere mestre å leve med øyesykdommen sin.

\section{Forfattere}

\section{Katrine Vikås Paulsen}

Øyesykepleier og fagutviklingssykepleier

Øye poliklinikk / dagkirurgi, Stavanger universitetssjukehus

Ingunn Langvik Tveit

Øyesykepleier

Øye poliklinikk, Stavanger universitetssjukehus

\section{Sissel Eikeland Husebø}

Førsteamanuensis og forskningskoordiantor

Avdeling for kvalitet og helseteknologi, Det helsevitenskapelige fakultet, Universitetet i Stavanger

\section{Nøkkelord}

Informasjon Mestring Pårørende Pasient

Sykepleien 2018 106(70578)(e-70578)

DOI: https://doi.org/10.4220/Sykepleiens.2018.70578 
Øyeavdelingen ved Stavanger universitetssjukehus (SUS) har arrangert informasjonsmøte på kveldstid for pasienter med aldersrelatert makuladegenerasjon (AMD). Erfaringene har vært så positive for pasientgruppen at vi nå har arrangert et slikt møte for andre året på rad. Informasjonsmøter på kveldstid kan gi pasientene økt kunnskap, slik at de bedre mestrer å leve med sin øyesykdom.

Informasjonsmøtet er også for pårørende og andre interesserte og arrangeres i samarbeid med synskontakten og hjelpemiddelsentralen i Stavanger kommune. Injeksjonsklinikken er en del av øyeavdelingen. Avdelingen er strømlinjeformet med tidspress der det kan være lite rom for spørsmål fra pasienter og pårørende.

\section{Kort om AMD}

Aldersrelatert makuladegenerasjon (AMD) innebærer at det skjer en nedbrytning av det innerste laget i retina, i den gule flekken, som kalles makula. I makula sitter skarpsynet (detaljsynet). Degenerasjon skyldes opphopning av avfallsstoffer. Sykdommen gir en svekkelse av skarpsynet. AMD deles inn i to underdiagnoser, nemlig tørr og våt AMD. Våt AMD behandles med injeksjoner. Det eksisterer ingen behandling ved tørr AMD (1).

Pasienter med AMD får behandling med jevnlige injeksjoner av medisiner som for eksempel Eylea og Avastin. I forkant av injeksjonsbehandling er det legen som informerer pasienten. Informasjonen blir gjentatt dersom pasienten har behov for det.

\section{Bakgrunn for møtet}

Øyeavdelingen ved Stavanger universitetssjukehus

(SUS) startet opp med injeksjonsklinikk i 2005. Da ble det utført 49 injeksjoner. Etter 2005 har det vært en jevn økning, og i 2016 utførte vi cirka 5000 injeksjoner. 
På disse årene har det skjedd en stor endring i hvordan injeksjonsklinikken blir organisert. Mellom 2012 og 2014 ble det gjennomført en omstrukturering. Injeksjonsklinikken flyttet i eget bygg, vi har tatt i bruk elektronisk injeksjonsskjema i den elektroniske pasientjournalen DIPS, og det har skjedd en oppgaveglidning. Disse faktorene har ført til en effektivisering av injeksjonsklinikken.

\section{«Vi ønsker å gi pasienter og pårørende et tilbud utenom vanlig arbeidstid ved å arrangere informasjonsmøter på kveldstid.»}

Flertallet av dem som får injeksjon i øynene på grunn av AMD, er eldre mennesker (1). De har behov for injeksjon på ett øye eller begge øynene. Andre øyediagnoser, som for eksempel diabetes makulaødem og retinal veneokklusjon, behandles også med injeksjon.

Andre øyeavdelinger arrangerer AMD-skole på dagtid. Vi ønsker å gi pasienter og pårørende et tilbud utenom vanlig arbeidstid ved å arrangere informasjonsmøter på kveldstid. Siden pasienter med AMD utgjør hovedgruppen som får injeksjon på injeksjonsklinikken, er det disse pasientene som inviteres til informasjonsmøte.

\section{Poliklinisk tilbud}

Injeksjonsklinikken er åpen fra mandag til torsdag, og til sammen 30 pasienter blir behandlet per dag. Injeksjonsklinikken tilbyr følgende tredelte forløp:

- Pasienten kommer først inn til en sykepleier, som sjekker synet, måler øyetrykket og administrerer dilaterende øyedråper.

- Pasienten møter deretter helsesekretæren, som tar foto av øyebunnen ved hjelp av optisk koherent tomografi (OCT - Optical Coherence Tomography).

- Pasienten møter øyelegen og sykepleieren på injeksjonsrommet. 
Behandlingsopplegget «treat and extend» innebærer at pasienten får månedlig behandling i tre måneder.

Deretter forlenges intervallet med to uker hvis behandlingen har hatt god effekt. Øyelegen vurderer bilder av øyebunnen og setter injeksjonen.

Sykepleieren og legen dokumenterer i et eget skjema i DIPS hver gang pasienten er til kontroll.

Sykehusapoteket trekker opp injeksjonsmedisin etter gjeldende retningslinjer og prosedyrer.

\section{Brukerunders $\varnothing$ kelse}

Vinteren 2017 utførte vi ved øyeavdelingen en brukerundersøkelse for pasienter med AMD. 107 brukere deltok i spørreundersøkelsen. Vi anvendte utvalgte spørsmål fra PasOpp-spørreskjemaet (2). Det inneholdt seks temaer med totalt 18 spørsmål, der fire spørsmål omhandlet informasjon. Erfaringene viste at spørsmålene ble for generelle, men resultatene viste likevel at et stort antall pasienter var fornøyde med dagens tilbud.

Vår erfaring er at mange pasienter ikke stiller spørsmål mens de er på injeksjonsklinikken fordi personalet er så travelt. I pasientgruppen med AMD er det mange eldre mennesker som har stor respekt for helsepersonell, og som ikke ønsker å være til bry.

\section{三 «Vår erfaring er at mange pasienter ikke stiller spørsmål mens de er på injeksjonsklinikken fordi personalet er så travelt.»}

Øyeavdelingen ønsket å gjøre noe med dette. Først lagde vi en informasjonsbrosjyre skrevet på et enkelt språk og som er lett tilgjengelig på injeksjonsklinikken. Deretter ønsket vi å arrangere et informasjonsmøte for pasienter og pårørende på kveldstid.

\section{Informasjonsmøtet}


Pasientene blir orientert om informasjonsmøtet på injeksjonsklinikken god tid i forveien. Vi henger også opp plakater lett synlig. I tillegg orienterer vi alle private øyeleger i Stavanger og omegn om informasjonsmøtet. Informasjonsmøtet er fra kl. 18.00 til 20.00. Det er bindende påmelding på grunn av gratis servering.

Øyelegen starter møtet med å informere på et enkelt språk om sykdom og behandling. Deltakerne blir oppfordret til å stille spørsmål underveis. Deretter er det pause med enkel servering og rom for spørsmål fra pasienter og pårørende.

Deltakerne får også tilbud om å få demonstrert hjelpemidler. Synskontakten og Hjelpemiddelsentralen avslutter informasjonsmøtet med å informere om de ulike hjelpemidlene som finnes, og opplyse hvordan pasienten kan ta kontakt med dem.

Det var 70 deltakere på informasjonsmøtene både i 2016 og 2017.

\section{Nytteverdi}

I etterkant av informasjonsmøtet i 2017 ble deltakerne spurt om de ville fylle ut et tilbakemeldingsskjema. Det var cirka 15 deltakere som svarte. Selv om et fåtall av deltakerne svarte skriftlig, var det mange av deltakerne som ga muntlig tilbakemelding rett etter at møtet var slutt.

Inntrykket vårt var at mange mente at møtet var med på å gi dem trygghet fordi de fikk kunnskap om og lærte å mestre det å leve med øyesykdom. De vurderte at det var nyttig med informasjonen om sykdommen og ulike hjelpemidler.

\section{Veien videre?}


Øyeavdelingen ønsker også i fremtiden å arrangere informasjonsmøte én gang per år for pasienter med AMD. Vi skal også gjennomføre en ny brukerundersøkelse vinteren 2019 med de samme spørsmålene fra PasOpp-undersøkelsen fra

Folkehelseinstituttet (2).

\section{三 «Øyeavdelingen får viktige tilbakemeldinger om hva som fungerer bra, og hva vi bør forbedre.»}

Pasienten får gitt sin tilbakemelding på behandlingen

og helsetilbudet i brukerundersøkelsen og

tilbakemeldingsskjemaet. Ved å gjennomføre

informasjonsmøter på kveldstid med informasjon som alle kan forstå, får øyeavdelingen viktige tilbakemeldinger om hva som fungerer bra, og hva vi bør forbedre. Dermed blir pasientene våre enda mer fornøyde med helsetilbudet de mottar.

\section{Referanser}

1. Sansetap. Aldersrelatert makula degenerasjon (AMD) [internett]. Oslo: Helsedirektoratet og Statped; 06.09.2012 [oppdatert 21.02.2018, sitert 25.04.2018]. Tilgjengelig fra: http://www.sansetap.no/diagnoser-ogtilstander/syn/makula-macula-degenerasjon/.

2. Folkehelseinstituttet. Spørreskjemabanken [internett]. Oslo: Folkehelseinstituttet; 04.10.2014 [sitert 02.03.2018]. Tilgjengelig fra https://www.fhi.no/kk/brukererfaringer/sporreskjemabanken2/. 